\title{
Spesiasi Aluminium Terlarut dan Sifat Kimia Ultisol yang Diameliorasi dengan Dolomit dan Lignit-Teraktivasi
}

\section{(Soluble Aluminum Speciation and Chemical Properties of Ultisol Amended with Dolomite and Activated-Lignite)}

\author{
Fahmi Arief Rahman ${ }^{1 *}$, Budi Nugroho ${ }^{2}$, Atang Sutandi ${ }^{2}$, Untung Sudadi ${ }^{2}$
}

(Diterima April 2019/Disetujui Juni 2020)

\begin{abstract}
ABSTRAK
Fitotoksisitas aluminium (Al), baik secara langsung pada pertumbuhan tanaman maupun secara tidak langsung melalui peningkatan kemasaman tanah, berkaitan erat dengan keberadaan berbagai spesies Al dalam larutan tanah. $\mathrm{Al}^{3+}$ dan Al-monomer merupakan spesies utama Al-terlarut penyebab fitotoksisitas pada tanah berkadar Al tinggi. Penelitian ini bertujuan mengevaluasi pengaruh ameliorasi dolomit dan batubara muda atau lignit teraktivasi-basa (LTB) pada perubahan spesies Al-terlarut dan sifat kimia tanah lainnya serta respons pertumbuhan vegetatif kedelai (Glycine max Merr) pada Ultisol Jasinga (Al-dd 16,03 cmol(+)/kg). Percobaan rumah kaca dilakukan dalam Rancangan Acak Lengkap dengan ameliorasi dolomit dan LTB sebagai perlakuan, masing-masing dengan tiga taraf, yaitu 0,1 , 1,5 x Al-dapat ditukar (Al-dd) dan 0, 2,5, 5 ton/ha dan tiga ulangan. Amelioran diinkubasi satu minggu pada kondisi kadar air kapasitas lapang sebelum penanaman kedelai selama satu bulan. Spesiasi Al-terlarut tanah dilakukan dengan metode kolorimetri aluminon untuk menetapkan Al-terlarut total serta spesies Al-monomer inorganik, Almonomer organik, dan Al-polimer. Hasil penelitian menunjukkan bahwa hanya ameliorasi dolomit yang berpengaruh nyata meningkatkan $\mathrm{pH}-\mathrm{H}_{2} \mathrm{O}, \mathrm{pH}-\mathrm{KCl}, \mathrm{Ca}-\mathrm{dd}$, Na-dd tanah, dan penurunan kadar Al-dd, kecuali pada kadar semua spesies Al-terlarut yang hanya menunjukkan kecenderungan menurun. Kadar Al-dd tanah berkorelasi nyata negatif dengan parameter ukur kedelai, yaitu tinggi, panjang akar, bobot basah, bobot kering, dan kadar Ca-tanaman. Hal ini mengindikasikan bahwa evaluasi fitotoksisitas Al tanah cukup didasarkan atas hasil analisis tanah rutin kadar Al-dd.
\end{abstract}

Kata kunci: Al-dapat ditukar, Al-monomer inorganik, Al-monomer organik, Al-polimer

\section{ABSTRACT}

Phytotoxicity of soil aluminum (Al), both directly to the plant growth as well as indirectly through the increase of soil potential acidity, is closely related to the occurrence of various soil soluble-Al species. Amongst them, $\mathrm{Al}^{3+}$ and monomeric-Al species are the primary causes of Al phytotoxicity in soils with high Al content. This study was aimed to evaluate the effects of soil amelioration with dolomite and base-activated lignite (BAL) on changes in soluble-Al species and other soil chemical properties, and vegetative growth of soybean (Glycine max Merr) on Ultisol of Jasinga (Al-dd 16,03 cmol(+)/kg). A green house experiment was conducted by applying a Completely Randomized Design with dolomite and BAL amelioration as the treatments, each with three levels of repectively $0,1,1,5 \times$ exchangeable$\mathrm{Al}$ and $0,2,5,5$ tons BAL ha-1, and three replications. The ameliorants were incubated at field capacity of soil moisture content for one week before planting soybean for one month. Soil soluble-Al speciation was carried out using colorimetric aluminon method to determine concentrations of total soluble-Al, monomeric-Al, and polymeric-Al species. Monomeric-Al were further speciated into inorganic monomeric-Al and organic monomeric-Al species. The results revealed that only dolomite amelioration that significantly increased soil $\mathrm{pH}-\mathrm{H} 2 \mathrm{O}, \mathrm{pH}-\mathrm{KCl}, \mathrm{Ca}-\mathrm{dd}, \mathrm{Na}-\mathrm{dd}$, and decreased exchangeable-Al concentration, except for those of all soluble-Al species that only showed a decreasing trend. Soil exchangeable-Al that was negatively and significantly correlated with soybean measure parameters were plant height, root length, total roots and shoots wet and dry weights, as well as Ca concentration. These results indicated that soil Al phytotoxicity evaluation could be relied on the result of routine analysis on soil exchangeableAl concentration.

Keywords: exchangeable-Al, inorganic monomeric-Al, organic monomeric-Al, polymeric-Al

\section{PENDAHULUAN}

Ultisol dapat memiliki kejenuhan Al lebih dari 30\% sehingga sangat berpeluang menimbulkan

\footnotetext{
1 Sekolah Pascasarjana, Program Studi IImu Tanah, Institut Pertanian Bogor, Kampus IPB Darmaga, Bogor 16680

2 Departemen IImu Tanah dan Sumberdaya Lahan, Fakultas Pertanian IPB, Institut Pertanian Bogor, Kampus IPB Darmaga, Bogor 16680

* Penulis Korespondensi: Email: mailnyafahmi@gmail.com
}

fitotoksisitas atau keracunan Al bagi tanaman. Gejala umum fitotoksisitas Al adalah hambatan pertumbuhan akar (Yang \& Horst 2015). Fitotoksisitas Al berkaitan erat dengan keberadaan berbagai bentuk kimia atau spesies $\mathrm{Al}$, terutama pada fasa larutan tanah. $\mathrm{Al}^{3+}$ dan Al-monomer inorganik, seperti Al-F dan $\mathrm{Al}-\mathrm{SO}_{4}$, merupakan spesies utama Al-terlarut tanah penyebab fitotoksisitas dan merupakan indikator yang sensitif 
berkaitan dengan cekaman akar dan pertumbuhan tanaman di tanah masam (Shen et al. 2008).

Solusi permasalahan fitotoksisitas $\mathrm{Al}$ pada tanah mineral masam, seperti Ultisol, antara lain adalah dengan aplikasi amelioran, seperti kapur dolomit $\left[(\mathrm{CaMg})_{2} \mathrm{CO}_{3}\right]$ dan bahan penjerap atau adsorbent $\mathrm{Al}$ berbasis karbon, seperti lignit atau batubara muda teraktivasi. Berbagai penelitian telah membuktikan bahwa dolomit efektif dalam menurunkan kelarutan Al dan meningkatkan $\mathrm{pH}$ tanah. Lignit teraktivasi-basa dilaporkan memiliki kapasitas adsorpsi tinggi terhadap Al. Kapasitas adsorpsi lignit tanpa aktivasi Al dilaporkan 286-370 $\mathrm{mg} \cdot \mathrm{g}^{-1}$ dan mencapai $435 \mathrm{mg} \cdot \mathrm{g}^{-1}$ dengan perlakuan aktivasi basa (Qi et al. 2011).

Aktivasi lignit dapat dilakukan dengan teknik fisika melalui pemanasan dan teknik kimia melalui penambahan basa, seperti $\mathrm{KOH}$ atau garam-garam klorida, seperti $\mathrm{NaCl}, \mathrm{KCl}, \mathrm{CaCl}_{2}, \mathrm{MgCl}_{2}$, dan $\mathrm{AlCl}_{3}$ (loannidou dan Zabaniotou 2007). Deprotonisasi gugus-gugus fungsional $\mathrm{OH}$-terbuka pada permukaan adsorbent (Tan 2011), seperti lignit, merupakan mekanisme aktivasi kimiawi yang menyebabkan peningkatan kerapatan muatan negatif sehingga lignit teraktivasi menjadi lebih reaktif dalam mengadsorpsi kation logam, seperti Al. Kombinasi ameliorasi dolomit dan lignit teraktivasi-basa (LTB) diharapkan lebih efektif untuk mengatasi permasalahan kesuburan kimia tanah dan pertumbuhan tanaman pada tanah berkadar Al tinggi. Penelitian ini bertujuan mengevaluasi pengaruh ameliorasi dolomit dan LTB pada perubahan spesies Al-terlarut dan sifat kimia tanah lainnya serta respons pertumbuhan vegetatif kedelai pada Ultisol Jasinga.

\section{METODE PENELITIAN}

\section{Tempat dan Waktu}

Contoh tanah ruah (bulk soil samples) diambil secara komposit pada lapisan $30 \mathrm{~cm}$ teratas area kebun campuran di Kecamatan Jasinga, Kabupaten Bogor, Jawa Barat pada posisi koordinat 645'56" LS dan 10644'91" BT. Contoh lignit diperoleh dari area tambang di Kabupaten Lebak, Banten. Percobaan dilakukan di rumah kaca Kebun Percobaan Cikabayan, Fakultas Pertanian, IPB. Analisis kimia tanah, dolomit, lignit, dan jaringan tanaman dilakukan di Laboratorium Kimia dan Kesuburan Tanah, Depertemen IImu Tanah dan Sumberdaya Lahan, Fakultas Pertanian, IPB. Penelitian dilakukan sejak April-September 2018.

\section{Rancangan Penelitian}

Bahan utama penelitian ini meliputi tanah pucuk Ultisol Jasinga kering udara yang lolos saringan $2 \mathrm{~mm}$, dolomit, LTB, benih kedelai, dan bahan-bahan kimia. Bahan LTB dipersiapkan dengan proses aktivasi kimiawi, yakni mencampurkan 5,92 g KOH.kg-1 lignit yang telah lolos saringan $2 \mathrm{~mm}$ lalu diberi air sampai kapasitas lapang kemudian diinkubasi selama satu minggu sebelum dicampurkan dengan Ultisol Jasinga.
Percobaan rumah kaca dilakukan dalam RAL Faktorial dengan ameliorasi dolomit dan LTB sebagai perlakuan, masing-masing dengan tiga taraf, yaitu 0,1 , dan $1,5 \mathrm{x}$ Al-dd serta 0, 2,5, dan 5 ton LTB.ha ${ }^{-1}$ dan tiga ulangan. Amelioran diinkubasi dalam kondisi kadar air tanah pada kapasitas lapang satu minggu sebelum penanaman dan pemeliharaan kedelai selama satu bulan. Pengamatan pertumbuhan vegetatif kedelai dilakukan pada tinggi, panjang akar, serta bobot basah dan bobot kering total akar dan tajuk. Pada akhir masa percobaan dilakukan analisis tanah berupa $\mathrm{pH}-\mathrm{H}_{2} \mathrm{O}$, $\mathrm{pH}-\mathrm{KCl}, \mathrm{KTK}, \mathrm{C}-$ organik, K-dd, Na-dd, Ca-dd, Mg-dd, Al-dd, spesiasi Al-terlarut, dan jaringan tanaman. Analisis data dilakukan dengan anova pada semua parameter, dan dilanjutkan dengan DMRT bagi parameter yang dipengaruhi secara nyata (5\%). Analisis korelasi Pearson dilakukan antarparameter tanah dan tanaman.

\section{Prosedur Analisis Laboratorium}

Analisis tanah, dolomit, LTB, dan jaringan tanaman dilakukan dengan metode rutin. Spesiasi Al-terlarut tanah dilakukan dengan metode kolorimetri aluminon (Hsu 1963). Larutan tanah untuk spesiasi Al-terlarut diperoleh dengan mengekstraksi tanah menggunakan pengekstrak Morgan atau larutan 10\% Na-asetat dengan nisbah tanah:pelarut 1:10 (Jones dan Thurman 1957).

Kadar Al-total terlarut ditetapkan dengan menambahkan $\pm 25 \mathrm{~mL}$ aquades, $2 \mathrm{~mL}$ larutan thioglycollic acid, dan 1,2 $\mathrm{mL} N \mathrm{HCl}$ ke labu takar-50 $\mathrm{mL}$ berisi $4 \mathrm{~mL}$ larutan tanah; kemudian dipanaskan dalam water bath $\left(80^{\circ} \mathrm{C}, 30\right.$ menit), didinginkan 1-2 jam, ditambahkan $10 \mathrm{~mL}$ larutan aluminon-asetat buffer, ditera dengan aquades, dan didiamkan 30 menit. Kadar Al ditetapkan menggunakan seri larutan standar yang disiapkan dari $0,1,2, \ldots 6 \mathrm{~mL}$ larutan 5 ppm Al dari $0.001 M \mathrm{Al}\left(\mathrm{NO}_{3}\right)_{3}$. Kadar Al-monomer ditetapkan dengan prosedur seperti penetapan Alterlarut total tanpa penambahan $\mathrm{HCl}$ dan pemanasan dalam water bath. Kadar Al-polimer adalah selisih antara kadar Al-terlarut total dan Al-monomer.

Spesies Al-monomer dispesiasi lebih lanjut sebagai Al-monomer inorganik dan Al-monomer organik (Kerven et al. 1989). Kadar Al-monomer inorganik ditetapkan dengan prosedur seperti penetapan Almonomer, namun menggunakan larutan standar yang disiapkan dengan mencampurkan $0.001 \mathrm{M} \mathrm{Al}\left(\mathrm{NO}_{3}\right)_{3}$ dan $0.010 \mathrm{M} \mathrm{Al}$ oksalat masing-masing dengan kadar 25, 50, dan $100 \mu \mathrm{M} \mathrm{Al}$; menambahkan $0.1 \mathrm{~mL} \mathrm{0,5 \%}$ asam askorbat dan $10 \mathrm{~mL}$ aluminon-asetat buffer 30 detik sebelum pengukuran. Larutan 0.010 $\mathrm{M} \mathrm{Al-oksalat}$ dibuat dengan melarutkan $126 \mathrm{mg}$ asam oksalat dalam $60 \mathrm{ml}$ aquades, menambahkan $1 \mathrm{~mL} 0.001 \mathrm{M} \mathrm{Al}\left(\mathrm{NO}_{3}\right)_{3}$; menyesuaikan $\mathrm{pH}$ larutan secara perlahan menjadi 4,5 menggunakan $M \mathrm{KOH}$ sambil terus diaduk; dan diencerkan dengan aquades hingga bervolume 100 $\mathrm{mL}$. Kadar Al-monomer organik adalah selisih antara kadar Al-monomer dan Al monomer inorganik. Kadar 
Al diukur menggunakan spektrofotometer pada panjang gelombang $530 \mathrm{~nm}$.

\section{HASIL DAN PEMBAHASAN}

Sifat kimia utama tanah yang digunakan dalam penelitian ini adalah bereaksi masam, berkadar Corganik dan KTK rendah, serta kejenuhan Al sangat tinggi (Tabel 1).

\section{Sifat Kimia Tanah}

Hasil anova dan DMRT menunjukkan hanya ameliorasi dolomit yang berpengaruh nyata pada $\mathrm{pH}$ $\mathrm{H}_{2} \mathrm{O}$, pH KCl, Ca-dd, dan Al-dd, namun tidak berpengaruh nyata pada C-organik dan $\mathrm{Mg}$-dd tanah (Tabel 2). LTB tidak berpengaruh nyata pada semua parameter tanah dan tanaman kecuali interaksi dolomit dan LTB hanya berpengaruh nyata pada KTK tanah (Tabel 3). Meskipun mengandung 40,34\% C-organik (Tabel 1), ameliorasi LTB hanya cenderung meningkatkan C-organik tanah. Demikian pula halnya dengan ameliorasi dolomit (Gambar 1).

Perlakuan LTB tidak berpengaruh nyata pada semua parameter karena jumlah komponen teraktivasi pada lignit bergantung pada ukuran partikel lignit yang digunakan, jenis basa pengekstrak, dan suhu proses ekstraksi (Hoffmann et al. 2012). Lignit berukuran 0.2 $\mathrm{mm}$ akan menghasilkan asam humat $17 \%$ lebih tinggi dibandingkan dengan lignit berukuran $2 \mathrm{~mm}$ dengan menggunakan pengekstrak $\mathrm{KOH}$, dan akan menghasilkan asam humat lebih tinggi 5\% dengan $\mathrm{NaOH}$. Pada temperatur $190^{\circ} \mathrm{C}$ akan menghasilkan asam humat $70 \%$ lebih tinggi dibandingkan pada suhu $130^{\circ} \mathrm{C}$. Temperatur tinggi juga akan meningkatkan muatan negatif pada asam humat (Cheng et al. 2019).

Meskipun berpengaruh nyata, ameliorasi dolomit hanya meningkatkan $\mathrm{pH} \mathrm{H}_{2} \mathrm{O}$ dari 4.06 tanpa dolomit menjadi 4,14 dengan ameliorasi dolomit $1 \times$ Al-dd. Hal ini menunjukkan bahwa harkat reaksi tanah menurun dari masam pada contoh tanah awal (Tabel 1) menjadi sangat masam pada akhir masa percobaan (Tabel 2).

Reaksi pengapuran menggunakan dolomit terjadi melalui tahapan pelarutan untuk menghasilkan $\mathrm{Ca}^{2+}$, $\mathrm{Mg}^{2+}$, dan $\mathrm{OH}^{-}\left[(\mathrm{Ca}, \mathrm{Mg}) \mathrm{CO}_{3}+\mathrm{H}_{2} \mathrm{O} \rightarrow \mathrm{Ca}^{2+}, \mathrm{Mg}^{2+}+\right.$ $\mathrm{HCO}_{3}{ }^{-}+\mathrm{OH}^{-}$, netralisasi $\mathrm{H}^{+}$di larutan tanah oleh $\mathrm{OH}^{-}$ membentuk $\mathrm{H}_{2} \mathrm{O}\left[\mathrm{OH}^{-}+\mathrm{H}^{+} \rightarrow \mathrm{H}_{2} \mathrm{O}\right]$, dan pertukaran $\mathrm{Al}^{3+}$ dan $\mathrm{H}^{+}$pada permukaan adsorpsi atau kompleks pertukaran klei tanah oleh $\mathrm{Ca}^{2+}, \mathrm{Mg}^{2+}$, dan $\mathrm{OH}^{-}$untuk selanjutnya bersenyawa dengan $\mathrm{OH}^{-}$dalam larutan tanah membentuk $\mathrm{Al}(\mathrm{OH})_{3}$ yang diendapkan dan $\mathrm{H}_{2} \mathrm{O}$ $\left[\mathrm{Ca}^{2+}, \mathrm{Mg}^{2+}+\right.$ klei tanah $+\mathrm{Al}^{3+}, \mathrm{H}^{+} \rightarrow$ klei tanah $+\mathrm{Ca}^{2+}$, $\left.\mathrm{Mg}^{2+}+\mathrm{Al}^{\beta+}, \mathrm{H}^{+}\right]$dan $\left[3 \mathrm{OH}^{-}+\mathrm{Al}^{\beta+} \rightarrow \mathrm{Al}(\mathrm{OH})_{3}(p) ; \mathrm{OH}^{-}+\right.$ $\mathrm{H}^{+} \rightarrow \mathrm{H}_{2} \mathrm{O}$ ]. Kecepatan pelarutan dolomit dalam menghasikan $\mathrm{OH}^{-}$menentukan kinetika peningkatan $\mathrm{pH}$ dan penurunan kadar Al-dd tanah (Nduwumuremyi 2013; Tisdale et al. 1985).

Tabel 1 Hasil analisis awal contoh tanah Ultisol Jasinga, dolomit, dan lignit

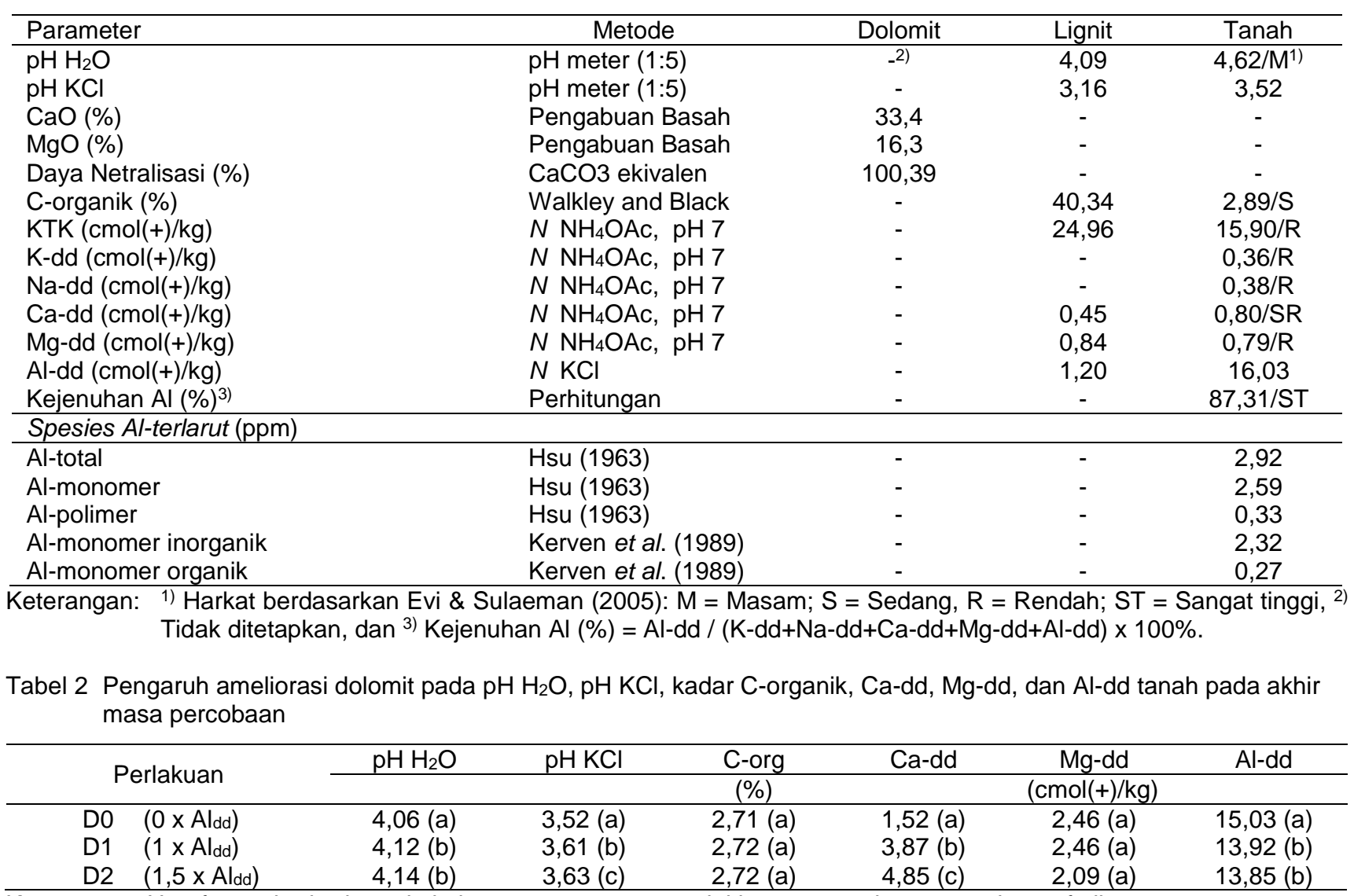

Keterangan: Huruf yang berbeda pada kolom yang sama menunjukkan pengaruh nyata pada taraf uji $5 \%$. 


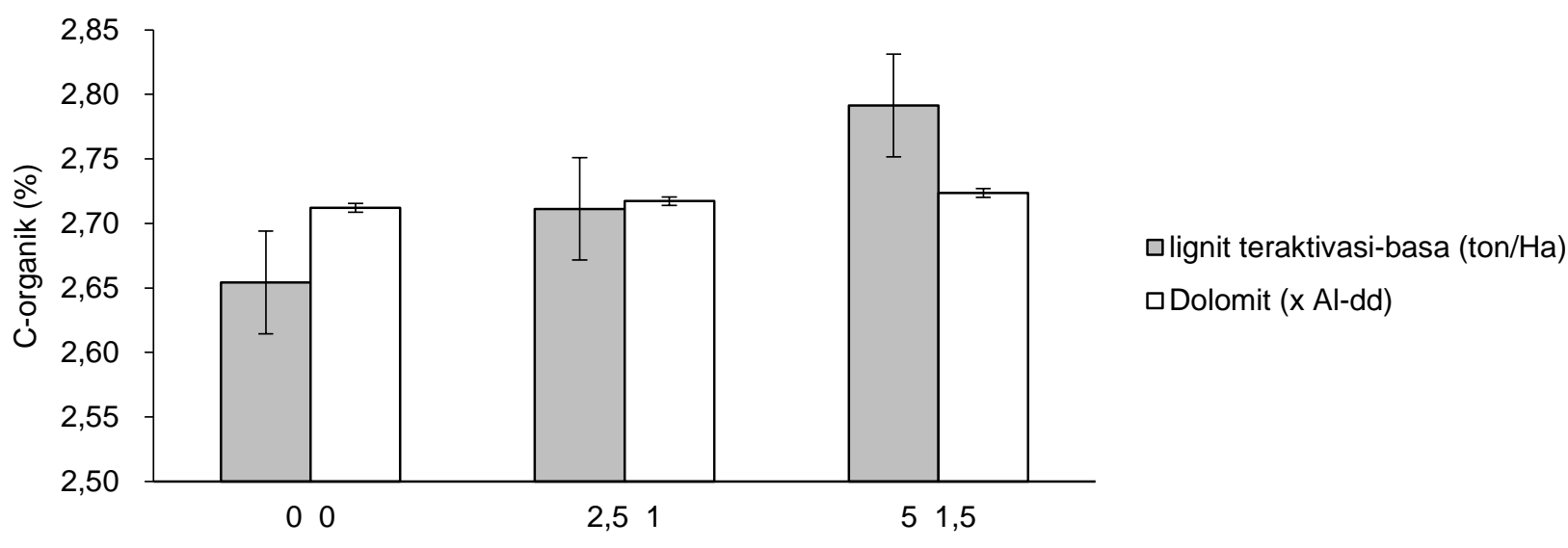

Gambar 1 Kecenderungan peningkatan kadar karbon organik tanah pada akhir masa percobaan akibat pengaruh tunggal ameliorasi dolomit atau lignit teraktivasi-basa.

Pengapuran dapat meningkatkan $\mathrm{pH}$, kejenuhan basa, C-organik, Ca-dd, dan Mg-dd serta mengurangi kadar dan fitotoksisitas Al dan Mn pada tanah masam (Fageria \& Stone 2004). Efisiensi bahan kapur ditentukan oleh daya netralisasi, ukuran dan distribusi partikel, dosis dan cara aplikasi yang menentukan rata tidaknya ketersediaan dan sebarannya dalam tanah (Foth \& Ellis 1996). Ameliorasi dolomit dengan dosis $1,5 \times$ Al-dd dalam penelitian ini meningkatkan kadar Ca-dd tiga kali lipat dibandingkan dengan tanpa dolomit (Tabel 2).

Pengaruh nyata interaksi ameliorasi dolomit dan LTB pada KTK (Tabel 3) berkaitan dengan reaksi pertukaran $\mathrm{H}^{+}$dan $\mathrm{Al}^{3+}$ dari kompleks jerapan. Dilaporkan bahwa $\mathrm{Ca}^{2+}$ dan $\mathrm{Mg}^{2+}$ dalam material berpori, seperti lignit, dapat meningkatkan kapasitas pertukaran dan efisiensi adsorpsi $\mathrm{Cu}^{2+}$, seperti dolomit (Cao et al. 2018). Peningkatan KTK akibat ameliorasi adsorbent organik, seperti lignit teraktivasi, juga terjadi melalui mekanisme deprotonasi gugus fungsional karboksil- dan fenol-OH pada bahan humik yang dikandungnya (Adani et al. 1998). Mekanisme ini meningkatkan muatan negatif sehingga meningkatkan KTK dan pelepasan $\mathrm{H}^{+}$yang dinetralkan oleh $\mathrm{OH}^{-}$dari dolomit sehingga $\mathrm{pH}$ tanah tetap meningkat (Tan 2011). KTK tanah pada taraf ameliorasi D2LTB0 lebih rendah daripada D2LTB1 dan D2LTB2 tetapi notasinya sama sehingga peningkatan KTK tanah lebih efisien hanya dengan ameliorasi dolomit pada dosis D2 tanpa LTB (Tabel 3).

Ameliorasi dolomit juga dapat meningkatkan Corganik tanah. Ameliorasi dolomit memberikan keuntungan dalam pembentukan C-organik tanah melalui proses fiksasi mikrobial (Xiao et al. 2016) oleh mikrob fotoautotrof seperti cyanobacteria maupun mikrob kemoautotrof, seperti carbon-monoxideoxidizing bacteria yang dapat mengasimilasi $\mathrm{CO}_{2}$ menjadi C-seluler (Wang et al. 2014) untuk selanjutnya menyumbang dan meningkatkan C-organik tanah. Lignit tersusun atas asam humik, asam fulvik, dan turunannya yang dapat menyumbang $\mathrm{C}$ organik tanah dan mengurangi fitotoksisitas $\mathrm{Al}^{3+}$ dan $\mathrm{Fe}^{3+}$ (Gerke 1993).

\section{Spesies Al-terlarut Tanah}

Ameliorasi dolomit dan LTB tidak berpengaruh nyata pada spesiasi Al-terlarut tanah (Tabel 4). Meskipun demikian, kadar Al-total terlarut, Almonomer, maupun Al-polimer cenderung menurun akibat ameliorasi dolomit. Hal ini terjadi karena $\mathrm{pH}$ tanah di akhir masa percobaan berharkat sangat masam sehingga adsorpsi Al cenderung lemah (Robles et al. 2016). Pelarutan dolomit menghasilkan $\mathrm{Ca}^{2+}, \mathrm{Mg}^{2+}$, dan $\mathrm{OH}^{-}$. Kedua kation tersebut akan melepaskan $\mathrm{Al}^{3+}$ dari kompleks pertukaran klei ke larutan tanah dan $\mathrm{OH}^{-}$akan mengubahnya menjadi spesies $\mathrm{Al}-\mathrm{OH}$ dengan berbagai tingkat kelarutan hingga menetralkannya menjadi endapan $\mathrm{Al}(\mathrm{OH})_{3}$. Kelarutan $\mathrm{Al}-\mathrm{OH}$ yang terbentuk bergantung pada $\mathrm{pH}$ tanah. Pada $\mathrm{pH}<4,5$, larutan tanah cenderung didominasi spesies Al-monomer, seperti yang terjadi pada penelitian ini (Tabel 4). Pada $\mathrm{pH}>4,5$ cenderung

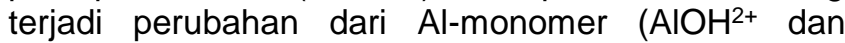
$\mathrm{Al}(\mathrm{OH})_{2}{ }^{+}$) menjadi Al-polimer, seperti $\mathrm{Al}_{6}(\mathrm{OH})_{15^{3+}}(\mathrm{Hsu}$ dan Rich 1960) hingga gibsit $\left[\mathrm{Al}(\mathrm{OH})_{3}\right]$ jika $\mathrm{pH}$ tanah meningkat lebih tinggi (Frink dan Peech. 1962).

\section{Pertumbuhan Vegetatif Kedelai}

Hasil anova menunjukkan bahwa hanya ameliorasi dolomit yang berpengaruh nyata positif pada tinggi, panjang akar, bobot basah, dan bobot kering kedelai (Tabel 5). Hal ini karena ameliorasi dolomit dapat meningkatkan ketersedian hara, terutama hara makro dan menekan fitotoksisitas Al (Fageria dan Stone 2004).

Keberadaan Al dalam tanah berpengaruh pada serapan hara, di antaranya $\mathrm{Ca}$ dan $\mathrm{Mg}$. Ameliorasi dolomit pada kadar $\mathrm{Al}$ dan $\mathrm{Mg}$ jaringan tanaman tidak nyata, meskipun cenderung meningkat dengan peningkatan taraf perlakuan, namun berpengaruh nyata positif pada kadar $\mathrm{Ca}$ jaringan tanaman (Tabel 6). Adanya anion hidroksida dan fosfat di zona perakaran menyebabkan penurunan $20 \%$ kadar Al 
Tabel 3 KTK tanah lignit teraktivasi basa pada $(\mathrm{cmol}(+) / \mathrm{kg})$

\begin{tabular}{ccccc}
\hline & \multirow{2}{*}{ Dolomit } & \multicolumn{3}{c}{ Lignit teraktivasi-basa } \\
\cline { 3 - 5 } & & LTB0 $(0$ ton/ha $)$ & LTB1 $(2,5$ ton/ha $)$ & LTB2 $(5$ ton/ha $)$ \\
\hline D1 & $(0 \times$ Aldd $)$ & $\left.17,07^{\mathrm{a} 1}\right)$ & $19,27^{\mathrm{c}}$ & $19,73^{\mathrm{cd}}$ \\
D2 & $\left(1.5 \times \mathrm{A} \mathrm{Al}_{\mathrm{ddd}}\right)$ & $19,40^{\mathrm{cd}}$ & $18,80^{\mathrm{b}}$ & $19,33^{\mathrm{c}}$ \\
\hline
\end{tabular}

Keterangan: ${ }^{1)}$ Huruf yang berbeda menunjukkan pengaruh nyata pada taraf uji $5 \%$.

Tabel 4 Pengaruh tunggal ameliorasi dolomit pada spesies Al-terlarut tanah pada akhir masa percobaan

\begin{tabular}{|c|c|c|c|}
\hline Perlakuan & Al-total (ppm) & Al-monomer (ppm) & Al-polimer (ppm) \\
\hline $\begin{array}{ll}\mathrm{D} 0 & \left(0 \times \mathrm{A} l_{\mathrm{dd}}\right)\end{array}$ & $2,91^{\text {a1) }}$ & $2,59^{a}$ & $0,32^{a}$ \\
\hline$\left(1 \times A l_{d d}\right)$ & $2,87^{a}$ & $2,56^{a}$ & $0,31^{a}$ \\
\hline D2 $\left(1.5 \times A l_{d d}\right)$ & $2,80^{\mathrm{a}}$ & $2,54^{\mathrm{a}}$ & $0,27^{a}$ \\
\hline
\end{tabular}

Keterangan: ${ }^{1)}$ Huruf yang sama pada kolom yang sama menunjukkan pengaruh tidak nyata pada taraf uji $5 \%$

Tabel 5 Pengaruh tunggal ameliorasi dolomit pada tinggi, panjang akar, bobot basah, dan bobot kering total akar dan tajuk kedelai pada umur satu bulan

\begin{tabular}{clcccc}
\hline & Perlakuan & Tinggi $(\mathrm{cm})$ & Panjang akar $(\mathrm{cm})$ & Bobot basah $(\mathrm{g})$ & Bobot kering $(\mathrm{g})$ \\
\hline D0 & $(0 \times$ Aldd $)$ & $15,73^{\mathrm{a} 1)}$ & $12,37^{\mathrm{a}}$ & $1,00^{\mathrm{a}}$ & $0,32^{\mathrm{a}}$ \\
D1 & $(1 \times \mathrm{Al}$ dd $)$ & $17,45^{\mathrm{b}}$ & $17,58^{\mathrm{b}}$ & $2,06^{\mathrm{b}}$ & $0,60^{\mathrm{b}}$ \\
D2 & $(1.5 \times$ Aldd $)$ & $19,22^{\mathrm{c}}$ & $18,92^{\mathrm{b}}$ & $2,21^{\mathrm{b}}$ & $0,67^{\mathrm{b}}$ \\
\hline
\end{tabular}

Keterangan: ${ }^{1)}$ Huruf yang berbeda pada kolom yang sama menunjukkan pengaruh nyata pada taraf uji $5 \%$.

Tabel 6 Pengaruh tunggal ameliorasi dolomit pada kadar Al, Ca, dan Mg jaringan kedelai pada umur satu bulan

\begin{tabular}{cccc}
\hline \multirow{2}{*}{ Perlakuan } & \multicolumn{3}{c}{ Kadar dalam jaringan kedelai umur satu bulan } \\
\cline { 2 - 4 } & $\mathrm{Al}(\%)$ & $\mathrm{Ca} \%)$ & $\mathrm{Mg}(\%)$ \\
\hline D0 $\quad(0 \times \mathrm{Al}$ dd $)$ & $\left.1,85^{\mathrm{a} 1}\right)$ & $0,09^{\mathrm{a}}$ & $0,07^{\mathrm{a}}$ \\
D1 $\quad(1 \times \mathrm{Al}$ dd $)$ & $2,31^{\mathrm{a}}$ & $0,18^{\mathrm{b}}$ & $0,07^{\mathrm{a}}$ \\
D2 $\quad(1.5 \times \mathrm{Al}$ dd $)$ & $2,09^{\mathrm{a}}$ & $0,23^{\mathrm{b}}$ & $0,09^{\mathrm{a}}$ \\
\hline
\end{tabular}

Keterangan: ${ }^{1)}$ Huruf yang sama pada kolom yang sama menunjukkan pengaruh tidak nyata pada taraf uji $5 \%$.

pada akar tanaman (Raynal et al. 1990) karena sebagian besar Al terpresipitasi sebagai Al-hidroksida atau Al-fosfat di luar sel akar (Clarkson 1966). Hal ini yang diduga sebagai penyebab kadar Al pada jaringan tanaman tidak berbeda nyata akibat ameliorasi dolomit. Ameliorasi dolomit pada taraf 1 kali Al-dd meningkatkan kadar Ca jaringan tanaman dua kali lipat dibandingkan tanpa perlakuan. Kadar $\mathrm{Ca}-\mathrm{dd}$ tanah meningkat secara nyata, sedangkan kadar Mg-dd tanah tidak berbeda nyata akibat perlakuan yang sama (Tabel 2). Hal ini sesuai dengan kadar $\mathrm{CaO}$ dolomit yang dua kali lipat dibandingkan MgO (Tabel 1).

Interaksi $\mathrm{Al}^{3+}$ dan $\mathrm{Ca}^{2+}$ merupakan faktor utama yang memengaruhi serapan dan transport $\mathrm{Ca}$ dalam jaringan tanaman. Endositosis $\mathrm{Al}^{3+}$ berperan dalam penyerapan kation tersebut (Akeson \& Unns 1990) sehingga kemungkinan $\mathrm{Al}^{3+}$ diserap tanaman melalui jalan masuk serapan $\mathrm{Ca}$ atau melalui saluran kation nonspesifik (Liu \& Luan 2001). Hal ini yang diduga menyebabkan kecenderungan peningkatan kadar Al seiring dengan peningkatan kadar $\mathrm{Ca}$ jaringan tanaman. Peningkatan kadar Al dan Si yang seiring dengan serapan $\mathrm{Ca}$ dilaporkan terjadi pada akar gandum dengan genotipe sensitif maupun toleran $\mathrm{Al}$ (Silva et al. 2010). Sebaliknya, peningkatan kadar $\mathrm{Al}^{3+}$ dilaporkan menyebabkan penurunan kadar $\mathrm{Ca}^{2+}$ pada semua bagian akar gandum (Jones et al. 1998). $\mathrm{Al}^{3+}$ juga dapat menurunkan akumulasi serapan $\mathrm{Mg}^{2+}$ (Rengel \& Robinson 1989). Hal ini disebabkan oleh perubahan sifat dan struktur membran akar akibat fitotoksisitas Al (Taylor et al. 1998).

Dalam penelitian ini, kadar Al jaringan tanaman tidak berbeda nyata akibat perlakuan karena sebagian besar Al diduga terlokalisasi di akar atau ujung akar kedelai. Efek fitotoksisitas Al terlokalisasi pada zona transisi ujung akar (Sivaguru \& Horst 1998) atau pada zona apex meristem akar, seperti ujung, meristem, dan zona perpanjangan akar (Ryan et al. 1993). Adanya Al pada apex meristem akar dapat menghambat pertumbuhan tanaman, bukan karena penghambatan pertumbuhan akar vertikal maupun lateral melainkan karena gangguan mekanisme di dalam sel yang menyebabkan akar tidak dapat menyerap hara dan air (Samac \& Tesfaye 2003).

\section{Korelasi Al-dd dan Spesies Al-terlarut Tanah dengan Parameter Pertumbuhan Kedelai}

Hasil analisis korelasi Pearson menunjukkan kadar Al-dd tanah berkorelasi sangat nyata negatif dengan tinggi, panjang akar, bobot basah, bobot kering, dan kadar Ca-jaringan tanaman. Kadar Al-terlarut total hanya berkorelasi nyata negatif dengan tinggi tanaman, yang lebih disebabkan oleh kadar Almonomer inorganik daripada Al-monomer organik yang masing-masing berkorelasi nyata negatif dan positif dengan panjang akar kedelai (Tabel 7).

Menurut Blamey et al. (1983), $\mathrm{Al}^{3+}$ dan $\mathrm{Al}-\mathrm{OH}$ merupakan spesies Al-monomer inorganik tanah yang 
Tabel 7 Nilai korelasi Pearson yang nyata dan sangat nyata antarparameter pertumbuhan vegetatif kedelai umur satu bulan dengan kadar Al-dd dan spesies Al-terlarut tanah

\begin{tabular}{|c|c|c|c|c|c|}
\hline $\begin{array}{l}\text { Parameter pertumbuhan } \\
\text { vegetatif kedelai }\end{array}$ & & Al-dd & Al-total & $\begin{array}{c}\text { Al-monomer } \\
\text { inorganik }\end{array}$ & $\begin{array}{c}\text { Al-monomer } \\
\text { organik }\end{array}$ \\
\hline Tinggi & $\begin{array}{c}r \\
p \text { value }\end{array}$ & $\begin{array}{c}-0,69 \\
0,000^{* *}\end{array}$ & $\begin{array}{c}-0,40 \\
0,039^{\star}\end{array}$ & $\begin{array}{l}-0,35 \\
0,078\end{array}$ & $\begin{array}{c}0,35 \\
0,078\end{array}$ \\
\hline Panjang akar & $\begin{array}{c}r \\
p \text { value }\end{array}$ & $\begin{array}{l}-0,62 \\
0,001^{* *}\end{array}$ & $\begin{array}{l}-0,32 \\
0,098\end{array}$ & $\begin{array}{l}-0,45 \\
0,018^{*}\end{array}$ & $\begin{array}{c}0,45 \\
0,018^{*}\end{array}$ \\
\hline Bobot basah & $\begin{array}{c}r \\
p \text { value }\end{array}$ & $\begin{array}{l}-0,72 \\
0,000^{\star *}\end{array}$ & $\begin{array}{l}-0,19 \\
0,331\end{array}$ & $\begin{array}{l}-0,32 \\
0,101\end{array}$ & $\begin{array}{c}0,32 \\
0,101\end{array}$ \\
\hline Bobot kering & $\begin{array}{c}r \\
p \text { value }\end{array}$ & $\begin{array}{c}-0,71 \\
0,000^{* *}\end{array}$ & $\begin{array}{l}-0,19 \\
0,329\end{array}$ & $\begin{array}{l}-0,29 \\
0,154\end{array}$ & $\begin{array}{c}0,29 \\
0,154\end{array}$ \\
\hline Kadar Ca-jaringan & $\begin{array}{c}r \\
p \text { value }\end{array}$ & $\begin{array}{l}-0,60 \\
0,001^{* *}\end{array}$ & $\begin{array}{l}-0,26 \\
0,194\end{array}$ & $\begin{array}{l}-0,33 \\
0,094 \\
\end{array}$ & $\begin{array}{c}0,33 \\
0,094 \\
\end{array}$ \\
\hline
\end{tabular}

Keterangan: * Sangat nyata $(p<0,01)$ dan ${ }^{* *}$ Nyata (nilai $\left.p<0,05\right)$.

berperan dalam penghambatan pertumbuhan akar kedelai. Kadar Al-monomer inorganik 9.3 $\mu \mathrm{M}$ dalam larutan tanah akan mengurangi $50 \%$ pertumbuhan akar (Wright et al. 1987) karena hambatan proses pembelahan (Ryan et al. 2011) pada sel plumula dan radikula di fase awal perkecambahan (Ranal et al. 2016).

Berdasarkan hasil penelitian ini maka dapat dinyatakan bahwa evaluasi fitotoksisitas Al tanah cukup didasarkan atas hasil analisis rutin kadar Al-dd.

\section{KESIMPULAN}

Ameliorasi dolomit berpengaruh nyata meningkatkan $\mathrm{pH} \mathrm{H}_{2} \mathrm{O}, \mathrm{pH} \mathrm{KCl}$, Ca-dd tanah, tinggi, panjang akar, bobot basah, bobot kering, dan Catanaman, serta menurunkan Al-dd tanah. Interaksi ameliorasi dolomit dan lignin teraktivasi-basa berpengaruh nyata meningkatkan KTK tanah. Kadar Al-dd tanah berkorelasi nyata negatif dengan tinggi, panjang akar, bobot basah, bobot kering, dan Catanaman. Kadar Al-total hanya berkorelasi nyata negatif dengan tinggi tanaman, sedangkan kadar spesies Al-monomer inorganik dan Al-monomer organik masing-masing hanya berkorelasi nyata negatif dan positif dengan panjang akar kedelai.

\section{DAFTAR PUSTAKA}

Adani F, Genevini P, Zaccheo P, Zocchi G. 1998. The effect of commercial humic acid on tomato plant growth and mineral nutrition. Journal Plant Nutrition. 21(3): 561-575. https://doi.org/10.1080/01904169 809365424

Akeson M, Unns DN. 1990. Uptake of aluminum into root cytoplasm: Predicted rates for important solution complexes. Journal Plant Nutrition. 13: 467-484. https://doi.org/10.1080/019041690093 64093

Blamey FPC, Edwards DG, Asher CJ. 1983. Effects of Aluminum-OH:Al molar ratios and ionic strength on soybean root elongation in solution culture. Soil Science. 136: 197-207. https://doi.org/ 10.1097/00010694-198310000-00001

Cao ZF, Chen P, Yang F, Wang S, Zhong H. 2018. Transforming structure of dolomite to enhance its ion-exchange capacity for copper (II). Colloids and Surfaces A. 539: 201-208. https://doi.org/ 10.1016/j.colsurfa.2017.12.032

Cheng G, Niu Z, Zhang C, Zhang X, Li X. 2019. Extraction of humic acid from lignite by $\mathrm{KOH}$ hydrothermal Method. Applied Sciences. 9(1356): 1-13. https://doi.org/10.3390/app9071356

Clarkson DT. 1966. Effect of aluminum on the uptake and metabolism of phosphorus by barley seedlings. Plant Physiology. 41:16-172. https:// doi.org/10.1104/pp.41.1.165

Eviati, Sulaeman. 2005. Analisis Kimia Tanah, Tanaman, Air, dan Pupuk. Edisi ke-2. Bogor (ID): Balai Penelitian Tanah.

Fageria NK, Stone LF. 2004. Yield of common bean in no-tillage system with application of lime and zinc. Pesquisa Agropecuaria Brasileira. 73-78. https://doi.org/10.1590/S0100-204X20040001 00011

Foth HD, Ellis BG. 1996. Soil Fertility. $2^{\text {nd }}$ Ed. Boca Raton (CA): Lewis Publishers.

Frink CR, Peech M. 1962. The solubility of gibbsite in aqueous solution and soil extracts. Soil Science Society of America Journal 28: 346-347. https:// doi.org/10.2136/sssaj1962.0361599500260004001 $2 \mathrm{x}$

Gerke J. 1993. Aluminum complexation by humic substances and aluminum species in the soil solution. Geoderma. 63: 165-175. https:// doi.org/10.1016/0016-7061(94)90004-3

Hoffmann K, Huculak-Maczka M. 2012. Assessment of efficiency of humic acids extraction processusing different fineness of lignite. Ecolology Chemistry and Engineering A. 19(9): 1107-1113 
Hsu PH, Rich CL. 1960. Aluminum fixation in a synthetic cation exchanger. Soil Science Society of America Journal . 24: 21-25. https://doi.org/ 10.2136/sssaj1960.03615995002400010015x

Hsu PH. 1963. Effect of initial pH, phosphate and silicate on the determination of aluminum with aluminon. Soil Science 96(4): 230-238. https://d oi.org/10.1097/00010694-196310000-00002

Loannidou O, Zabaniotou A. 2007. Agricultural residues as precursors for activated Carbon production. Renewable \& Sustainable Energy Reviews. 11: 1966-2005. https://doi.org/10.1016/ j.rser.2006.03.013

Jones LH, Thurman DA. 1957. The determination of aluminium in soil, ash and plant materials using eriochrome cyanine R.A. Plant and Soil. 9: 131-141. https://doi.org/10.1007/BF01398921

Jones DL, Kochian LV, Gilroy S. 1998. Aluminum induces a decrease in cytosolic calcium concentration in BY-2 tobacco cell cultures. Plant Physiology. 116:81-89. https://doi.org/10.1104/ pp.116.1.81

Kerven GL, Edward DG, Asher CJ, Hallman PS, Kokot S. 1989. Aluminum determination in soil solution: II. Short-term colorimetric procedure for the measurement of inorganic monomeric aluminum in the presence of organic acid ligand. Australian Journal of Soil Research. 91-102. https:// doi.org/10.1071/SR9890091

Liu K, Luan S. 2001. Internal aluminum block of plant inward K+ channels. Plant Cell. 13: 1453-1465. https://doi.org/10.1105/TPC.010016

Nduwumuremyi A. 2013. Soil acidification and lime quality: Sources of soil acidity, effects on plant nutrients, efficiency of lime, and liming requirements. Research and Reviews: Journal of Agriculture and Allied Sciences. 2: 26-32.

Qi Y, Hoadley AFA, Chaffee AL, Garnier G. 2011. Characterisation of lignite as an industrial adsorbent. Fuel. 90: 1567-1574. https:// doi.org/10.1016/j.fuel.2011.01.015

Ranal MA, Rodrigues CM, Teixeira WF, Oliveira AP, Romero R. 2016. Seed germination of Microlicia fasciculata, an apomictic and aluminium accumulator species: Unexpected intraspecific variability in a restricted neotropical savanna area. Flora 220: 8-16. https://doi.org/10.1016/ j.flora.2016.02.001

Raynal DJ, Joslin JD, Thornton FC, Schaedle M, Henderson GS. 1990. Sensitivity of tree seedlings to aluminum: III. Red spruce and loblolly pine. Journal of Environmental Quallity. 19: 180-187. https://doi.org/10.2134/jeq1990.004724250019000 20003x
Rengel Z, Robinson DL. 1989. Aluminum effects on growth and macronutrient uptake by annual ryegrass. Agronomy Journal. 81: 208-215. https://doi.org/10.2134/agronj1989.000219620081 00020014x

Robles I, Bustos E, Lakatos J. 2016. Adsorption study of mercury on lignite in the presence of different anions. Sustainable Environment Research. 26: 136-141. https://doi.org/10.1016/j.serj.2016.04.008

Ryan PR, Ditomaso JM, Kochian LV. 1993. Aluminum toxicity in roots: An investigation of spatial sensitivity and the role of the root cap. Journal of Experimental Botany. 44: 437-446. https://doi.org/ 10.1093/jxb/44.2.437

Ryan PR, Tyerman SD, Sasaki T, Furuichi T, Yamamoto Y, Zhang WH, Delhaize E. 2011. The identification of aluminum resistance genes provides opportunities for enhancing crop production on acid soils. Journal of Experimental Botany. 62: 9-20. https://doi.org/10.1093/ jxb/erq272

Samac DA, Tesfaye M. 2003. Plant improvement for tolerance to aluminum in acid soil, a review. Plant Cell Tissue and Organ Culture. 75: 189-207. https://doi.org/10.1023/A:1025843829545

Shen RF, Yang ZM, Zheng SJ. 2008. Behavior of Aluminum in Soil-Plant Systems and Adaptation Mechanisms to Aluminum Toxicity In Plants. Beijing $(\mathrm{CHN})$ : Science Press.

Silva S, Pinto-Carnide O, Martins-Lopes P, Matos M, Guedes-Pinto H, Santos C. 2010. Differential aluminum changes on nutrient accumulation and root differentiation in an Al sensitive vs tolerant wheat. Environmental and Experimental Botany. 68:91-98. https://doi.org/10.1016/j.envexpbot. 2009.10.005

Sivaguru M, Horst WJ. 1998. The distal part of the transition zone is the most aluminum-sensitive apical root zone of maize. Plant Physiology. 116: 155-63. https://doi.org/10.1104/pp.116.1.155

Tan KH. 2011. Prinsiple of Soil Chemistry. $4^{\text {th }}$ Ed. Georgia (US): CRC Press.

Taylor GJ, Blamey FPC, Edwards DG. 1998. Antagonistic and synergistic interactions between aluminum and manganese on growth of Vigna unguiculata at low ionic strength. Physiologia Plantarum 104: 183-194. https://doi.org/ 10.1034/j.1399-3054.1998.1040206.x

Tisdale SL, Nelson WL, Beaton JD. 1985. Soil Fertility and Fertilizer. $4^{\text {th }}$ ed. London (UK): Colier Mc. Millan.

Wang Y, Wang L, Shan Y, Hu J, Tsang Y, Hu Y, Fu X, Le Y. 2014. Optimization of inorganic carbon sources to improve the carbon fixation efficiency of 
non-photosynthetic microbial community with different electron donors. Environmental Technology. 36(9-12): 1246-1255. https://doi.org/ 10.1080/09593330.2014.983991

Wright RJ, Baligar VC, Wright SF. 1987. Estimation of phytotoxic aluminum in soil solution using three spectrophotometric methods. Soil Science Society of America Journal. 114(3): 224-232. https:// doi.org/10.1097/00010694-198709000-00009
Xiao L, Sun Q, Yuan H, Li X, Chu Y, Ruan Y, Lian B. 2016. A feasible way to increase carbon sequestration by adding dolomite and K-feldspar to soil. Cogent Geoscience 2(1205324): 1-11. https://doi.org/10.1080/23312041.2016.1205324

Yang ZB, Horst WJ. 2015. Aluminum-induced inhibition of root growth: Roles of cell wall assembly, structure, and function. Springer. 24: 253-274. https://doi.org/10.1007/978-3-319-19968-9_13 